\title{
KENCUR (Kaempferia galanga) DAN BIOAKTIVITASNYA
}

\author{
Marina Silalahi \\ Pendidikan Biologi FKIP Universitas Kristen Indonesia, Jakarta Indonesia \\ marina_biouki@yahoo.com
}

Received: 13 April 2019 Accepted: 1 Juni 2019 Published: 30 Juni 2019

\begin{abstract}
Abstrak
Kaempferia galanga (KG) atau kencur telah lama digunakan masyarakat Asia termasuk Indonesia sebagai obat tradisional dan bumbu masak. Informasi yang konfrehensif botani, metabolit sekunder dan bioaktivitas $\mathrm{KG}$ sangat penting untuk pengembangannya sebagai obat tradisional sehingga dapat meminimalisasi efek sampingnya. Penulisan artikel ini didasarkan studi literatur yang diperoleh secara on line maupun off line berupa buku, jurnal maupun hasil penelitian lainnya. KG merupakan tanaman herba aromatis dengan daun biasanya 2-3(-5) dengan seludang 1,5-5 cm, daun sering horizontal dan menutupi permukaaan tanah. Ethyl-trans-p-methoxy cinnamate dan trans-ethyl cinnamate merupakan senyawa utama yang sangat penting pada KG dan merupakan komponen yang memiliki sifat pharmakologi, oleh karena itu penting dilakukan pemilihan aksesi dengan kandungan senyawa bioaktif yang tinggi. Secara etnobotani KG digunakan sebagai obat ekspektorat, karminatif, obat batuk, rematik, dan anti kanker, kolera, vasorelaksasi, anti mikroba, antioksidan, anti alergi penyembuhan luka. Walaupun secara etnobotani banyak manfaat dari KF, namun bioaktivitasnya membuktikan aktivitas KG sebagai anti kanker, anti oksidan, anti inflamasi, analgesik dan anti bakteri.
\end{abstract}

Kata kunci: Kaempfria galanga, anti kanker, Ethyl-trans-p-methoxy cinnamate

\begin{abstract}
Kaempferia galanga $(K G)$ or kencur has long been used by local communities in Asian such as Indonesia as traditional medicine and spices. The information is comprehensive about botany, secondary metabolites and bioactivity of $K G$ is very important for its development as traditional medicine so as to minimize its side effects. The writing of this article is based on the study of literature obtained on line or off line in the books, journals and the other research. $K G$ is an aromatic herbs with leaves usually 2-3 (5) with a sheath of 1.5-5 cm, leaves often horizontal and cover the surface of the soil. Ethyl-trans-pmethoxy cinnamate and trans-ethyl cinnamate are the main compounds that are very important in $K G$ and are components that have pharmacological properties, therefore it is important to select accessions with high bioactive compounds. The ethnobotany of $K G$ was used as a medicine for the directorate, carminative, cough, rheumatism, and anti-cancer drugs, cholera, relaxation, anti-microbial, antioxidant, anti-allergic wound healing. Although ethnobotany has many benefits from $K G$, its bioactivity proves the activity of $K G$ as an anti-cancer, anti-oxidant, anti-inflammatory, analgesic and anti-bacterial.
\end{abstract}

Keywords: Kaempferia galanga, anti cancer, Ethyl-trans-p-methoxy cinnamate

(C) 2019 LPPM IKIP PGRI Pontianak, Indonesia 


\section{PENDAHULUAN}

Kaempferia galanga (KG) atau kencur merupakan salah satu jenis dalam famili Zingiberaceae merupakan salah satu jenis tanaman obat penting bagi masyarakat Asia termasuk Indonesia. Raina et al. (2015) menyatakan di India, rhizoma KG digunakan sebagai salah satu bahan dalam praparasi obat-obat Ayurveda, pembuatan parfum, dan kosmetik. Oleh masyarakat lokal Indonesia, KG digunakan sebagai bahan jamu atau yang dikenal dengan jamu beras kencur dan sebagai bumbu masak.

Jamu beras kencur merupakan salah satu olahan jamu gendong (jamu segar yang diedarkan dengan cara menggendong) dengan KG dan beras (Oriza sativa) sebagai bahan utama. Nama jamu beras kencur berasal dari bahan utamanya beras dan kencur yang diyakini dapat meningkatkan nafsu makan, khususnya pada anak-anak. Pada pengolahan makanan rizoma KG digunakan dalam pembuatan berbagai kuliner tradisional Indonesia seperti pecel, gado-gado, dan karedok, sedangkan daun muda digunakan sebagai sayur atau lalaban. Makanan dengan bahan tambahan KG memiliki aroma khas, sehingga meningkatkan cita rasa makanan. Untuk memudahkan akses terhadap KG, masyarakat lokal Indonesia telah lama membudidayakan KG di pekarangan (Silalahi, 2019). Di pekarangan KG memiliki fungsi ganda yaitu sebagai bahan makanan, obat, tanaman hias dan juga mengurangi erosi.

Pemanfaatan KG sebagai bumbu masak dan obat berhubungan dengan metabolit sekundernya. Metabolit sekunder diproduksi oleh tumbuhan sebagai adaptasi atau untuk pertahanan pada lingkungan yang kurang menguntungkan. Alkaloid, senyawa fenolik dan terpenoid merupakan kelompok uatam metabolit sekunder yang dihasilkan tumbuhan (Harbone, 1987). Minyak atsiri atau dikenal juga sebagai essensial oil merupakan kelompok terpenoid khususnya monoterpenoid dan seskuiterpenoid yang mudah menguap pada suhu kamar (de Guzman dan Simionsma, 1999) dan memiliki aroma khas.

Secara etnobotani KG digunakan sebagai diare, malnutrisi, rematik, sakit maag, (Silalahi et al., 2015b), batuk, asma, gangguan saluran pencernaan, demam, ramuan untuk meigkatkan stamina, minuman ibu pasca melahirkan (Silalahi et al., 2015a), bahan sauna tradisional (Silalahi dan Nisyawati, 2018). Fabricant dan Farnsworth (2001) menyatakan bahwa sebanyak 80\% pengembangan obat didasarkan pada pemanfaatannya oleh berbagai etnis. Pemanfaatan KG sebagai obat tradisional juga diduga berhubungan dengan senyawa bioaktifnya terutama essensial oilnya. Kandungan essensial oil pada KG bervariasi dipengaruhi oleh berbagai faktor 
seperti lokasi, cara destilasi (Raina et al., 2015). Essensial oil telah lama digunakan dalam bidang pengobatan terutama sebagai aroma terapi, anti mikroba (Tewtrakul et al., 2005), dan antihipertensi.

Nopporncharoenku et al. (2017) menyatakan bahwa KG yang diperjual-belikan di pasar memiliki banyak variasi baik dari segi ukuran maupun karakter morfologi lainnya. Ketepatan bahan yang digunakan sebagai bahan obat merupakan salah satu faktor utama yang berhubungan dengan khasiatnya. Raina et al. (2015) menyatakan bahwa kandungan metabolit sekunder khusunya essensial oil pada KG sangat dipengaruhi oleh sumbernya. Di sisi lain deforestasi dan alih fungsi hutan mengakibatkan berbagai jenis tumbuhan rentan terhadap kepunahan. Nopporncharoenku et al. (2017) melaporkan bahwa beberapa spesies dari Keamperia telah langkah sehingga perlu pemahaman untuk melestarikaanya. Walaupun telah banyak penelitian tentang bioaktivitas dan metabolit sekunder KG, namun kompilasi secara konfrehensif mengenai botani, metabolit sekunder, manfaat, dan bioaktivitasnya masih terbatas. Artikel ini akan menjadi salah satu sumber untuk pengembangan KG sebagai obat tradisional maupun sebagai obat modern.

\section{METODE}

Penulisan artikel ini didasarkan studi literatur yang diperoleh secara on line maupun off line. Artikel on line berupa jurnal maupun hasil penelitian. Tulisan ini didasarkan pada kajian literatur baik secara online dan offline. Offline didasarkan pada berbagai buku literatur seperti Plants Resources of South East Asian dan buku lainnya. Media online didasarkan pada Web, Scopus, Pubmed, dan media on-line yang digunakan untuk publikasi dari berbagai Scientific journals.

\section{HASIL DAN PEMBAHASAN \\ ESSENSIAL OIL}

Essesial oil atau dikenal juga sebagai volatil oil merupakan salah satu senyawa yang mudah menguap dan sebagian besar berasal dari monoterpenoid dan seskuiterpenoid (Harbone, 1987; Taiz and Zeiger, 2006). Tumbuhan mensintesis essensial oil yang digunakan sebagai pertahanan terhadap serangan herbivora termassuk serangga (Liu et al., 2014). Kandungan 
essensial oil pada tanaman sangat dipengarui oleh berbagai faktor seperti cara destiliasai, sumber, organ dan umur tanaman (Raina et al., 2015; Rajendra et al., 2011).

Zingiberaceae merupakan salah satu famili yang menghasilkan essensial oil atau volatil oil, sehingga banyak digunakan dalam pengobatan. Esensial oil merupakan senyawa monoterpenoid dan seskuiterpenoid yang muda menguap (Taiz and Zeiger 2006). Rizoma KG mengandung monoterpenoids $(29,57 \%)$, sesquiterpenoids $(2,01)$, dan phenylpropanoids $(67,6)$ (Liu et al., 2014).

Kandungan essensial oil yang terdapat pada $\mathrm{Kg}$ dipengaruhi oleh berbagai faktor di antaranya sumber (Raina et al., 2015), cara ekstraksi, dan alat yang digunakan untuk analisis (Rajendra et al., 2011). KG yang dikoleksi dari bagian selatan India menunjukkan berbagai variasi kandungan essensial oil yaitu $\delta$-3-carene $(0,13-6,46 \%), 1,8$-cineole $(0,19-5,17 \%)$, borneol $(0,96-2,40 \%)$ dan pentadecane $(6,04-16,53 \%)$ (Raina et al., 2015). Hal yang berbeda dilaporkan oleh Tewtrakul et al., (2005) komponen utama volatile oil pada rizoma KG yang diperoleh dari Thailand dengan distilasi air adalah ethyl-p-methoxycinnamate (31,77\%), methylcinnamate $(23,23 \%)$, carvone $(11,13 \%)$, eucalyptol $(9,59 \%)$, dan pentadecane $(6,41 \%)$. Berbagai senyawa yang terdapat pada KG antara lain: 2-Propenoic acid, 3-(4-methoxyphenyl)-, ethyl ester (10,18\%), phthalic acid, 6-ethyloct-3-yl2-ethylhexyl ester (3,37\%), asam palmitat $(35,17 \%)$, sandaracopimaradiene $(8.20 \%)$, asam oleat $(22,15 \%)$, asam oktadekanoat $(10,10 \%)$, 2[2-(4-nonylphenoxy)ethoxy]ethanol $(3,57 \%)$ dan glycidyl stearate $(7,27 \%)$ diidentifikasi sebagai konstituen utama ektrak metanol KG oleh GC-MS analysis (Ali et al., 2018). Komponen utama dari rizoma $\mathrm{KG}$ ethyl-p-methoxycinnamate (38,6\%), ethyl cinnamate (23,2\%), 1,8-cineole (11,5\%), transcinnamaldehyde (5,3\%), dan borneol (5,2\%) (Liu et al., 2014). Variasi germplasm KG menunjukkan perbedaan yang signifiikan terhadap kandungan essensial oil rhizoma (Raina et al., 2015).

Berbagai metode digunakan untuk mengekstrasi essensial oil antara lain distrilasi air. Perbedaan larutan yang digunakan untuk mengekstrak berpengaruh terhadap senyawa yang dihasilkan. Rajendra et al. (2011) menyatakan bahwa rizoma KG yang diekstak dengan menggunakan petroleum mengandung sterols, triterpenoids dan resins: sedangkan jika diekstrak dengan menggunakan kloroform akan diperoleh, sterols, triterpenoids, flavanoids dan resins; sedangkan jika diekstrak dengan menggunakan metanol akan diperoleh steroids, triterpenoids, 
alkaloids, flavanoids, carbohydrates, resins dan protein; sedangkan jika diekstrak menggunakan air akan diperoleh saponins, carbohydrates dan protein.

Senyawa asam 2-Propenoic, asam phthalic, asam palmitic, sandaracopimara-diene, asam oleic, asam octadecanoic, 2-[2-(4-nonylphenoxy) ethoxy] ethanol dan glycidyl stearate merupakan kompone utama dari ekstrak metanol KG (Ali et al., 2018). Essential oil yang dihasilakan dari rhizoma KG antara lain: Tricyclene; $\alpha$-Pinene; Camphene; $\delta$-3-Carene; $\beta$ Cymene; 1,8-Cineole; Chrysanthenone; trans-Pinocarveol; Camphor; Borneol; p-Cymen-8-ol; Eucarvone; $p$-Anisaldehyde; trans-Cinnamaldehyde; Bornyl acetate; Sabinyl acetate; $\alpha$ Copaene; Cyperene; $\gamma$-Elemene; trans-Ethyl cinnamate; Ethyl cinnamate; $\gamma$-Muurolene; $\delta$ Cadinene; Calamenene; Spathulenol; Caryophyllene oxide; Zierone; dan Ethyl $p$ methoxycinnamate (Liu et al., 2014). Hal yang berbeda dilaporkan Ma et al (2015) bahwa essensial oil pada KG antara lain D-Limonene, Eucalyptol, Tridecane, Camphor, Borneol, Tetradecane, Copaene, Ethyl cinnamate, Germacrene D, Pentadecane, Cadinene, 3-Methyl tetradecane, a-calacorene, Hexadecane, Pentadecane,2,6,10-trimethyl-; Ethyl cis-pmethoxycinnamate; Cyclo-pentadecanone; 3-Ethenylcyclooctene; Heptadecane; Ethyl trans-pmethoxycinnamate; Methyl palmitate; 9, 12- methyl octadecadienoate; 9-Octadecenoic acid methyl ester; Methyl oleate.

Analisis kimia dari rhizoma KG dengan menggunakan GC dan GC/MS menunjukkan bahwa sebanyak 38 jenis senyawa kimia merpresentasikan 96,02 - 98,88\% dari semua esesnsial oil. Dua jenis senuwa essensial oil yang paling banyak ditemukan di rhizoma KG ethyl-trans-pmethoxycinnamate $(28,35-69,96 \%)$ dan trans-ethyl cinnamate (11,48-26,56\%) (Raina et al., 2015). Ethyl-trans-p-methoxy cinnamate dan trans-ethyl cinnamate merupakan senyawa utama yang sangat penting pada KG dan merupakan komponen yang memiliki sifat pharmakologi, oleh karena itu penting dilakukan pemilihan aksesi dengan kandungan senyawa bioaktif yang tinggi (Raina et al., 2015).

\section{BOTANI}

Kaemferia galanga merupakan salah satu jenis yang termasuk dalam famili Zingiberaceae. Zingiberaceae memiliki 53 genus dan lebih dari 1200 species (Kress, 1990), dan salah satu genusnya adalah Kaemferia. Nama genus Kaemferia diambil untuk commemorates Engelbert Kaempfer (1651-1716), seorang natularis dan fisika Jerman (Nayar 1985). Kaemferia memiliki sekitar 50 spesies (Larsen 1980) - 60 spesies (Nopporncharoenku et al., 2017) dan 
sebagian merupakan tumbuhan endemik. Kaempferia L. adalah genus berukuran sedang dalam famili Zingiberaceae. Noppornc- haroenku et al. (2017) melaporkan bahwa beberapa spesies dari Keamperia telah langkah sehingga perlu pemahaman untuk melestarikannya.

KG memiliki vernakuler name kencur (Indonesia), bataka (Sulawesi utara, Ternate, Tidore), cengkur (Malaysia), gisol (Filipina), disok (Iloko), East-Indian galanga (Inggris), dusol (Tagalog) (Ibrahim dalam de Padua et al., 1998), hasohor (Simalungun), keciwer (Karo, Phakpak) (Silalahi 2014). Tanaman ini diduga natif di India, namun telah tersebar luas di seluruh Asia Tenggara (Ibrahim 1999). Di Malaysia, rizoma digunakan untuk mengatasi hipertensi, keringat, ulcer, sprain, dan asma, sedangkan di Indonesia KF digunakan untuk mengatasi keringat, dan luka (Ibrahim 1999), rematik (Ibrahim 1999: Silalahi 2014).

Ciri ciri KG antara lain: merupakan herba kecil dan daun biasanya 2-3(-5) dengan seludang 1,5-5 cm, daun sering horizontal dan menutupi permukaaan tanah. Daun berbentuk elips hingga sub-orbicular dengan ukuran 6-15 cm x 2(-5)5-10 cm dengna ujung daun berbentuk acuminate. Pembungaan muncul diantara daun sesil dengan jumlah bunga 4-12(-15) bunga, dengan panjang kalik 2-3 cm dengan korolla yang bewrna putih, berbentuk tabung dengan ukuran 2,5-5 $\mathrm{cm}$ dan memiliki lobus $1,5-3 \mathrm{~cm}$. Labellum berentuk obovate dan terbagi hingga setengah bagian atu lebih dengan spot bewarna puti, ungu muda atau violet dibagian basal (Gambar 1). Staminoides berbentuk oblong-oblovate hingga oblanceolate dengan panjang 1,5- 3 cm bewarna putih, sedangkan stamen fertil memiliki ukuran 10-13 cm, dengan penghubung ybilobus yang dalam. Tanaman ini dapat tumbuh hingga ketinggian $1.000 \mathrm{~m}$ dpl (Ibrahim 1998).

Nopporncharoenku et al. (2017) melaporkan bahwa kromosom Kaemferia di Thailand sangat bervariasi dan banyak ditemukan poliploidi dengan kromosom $x=11$. Pengetahuan mengenai jumlah kromosom Kaemferia sangat penting terutama untuk pembiakan secara generatif. Lebih lanjut Nopporncharoenku et al. (2017) melaporkan dari 42 aksesi milik15 spesies Kaempferia di Thailand dan satu spesies dari Laos menunjukkan bahwa 14 aksesi diploid dan dua aksesi tetraploid. Tanaman triploid dan pentaploid sebaliknya tidak digunakan untuk membuat biji tetapi dibiakkan secara vegetatif (Nopporncharoenku et al., 2017). Nopporncharoenku et al. (2017) 29 diploid $(2 n=22)$ aksesi, lima triploid $(2 n=33)$, enam tetraploid $(2 n=44)$ dan dua aksesi pentaploid $(2 n=55)$. 

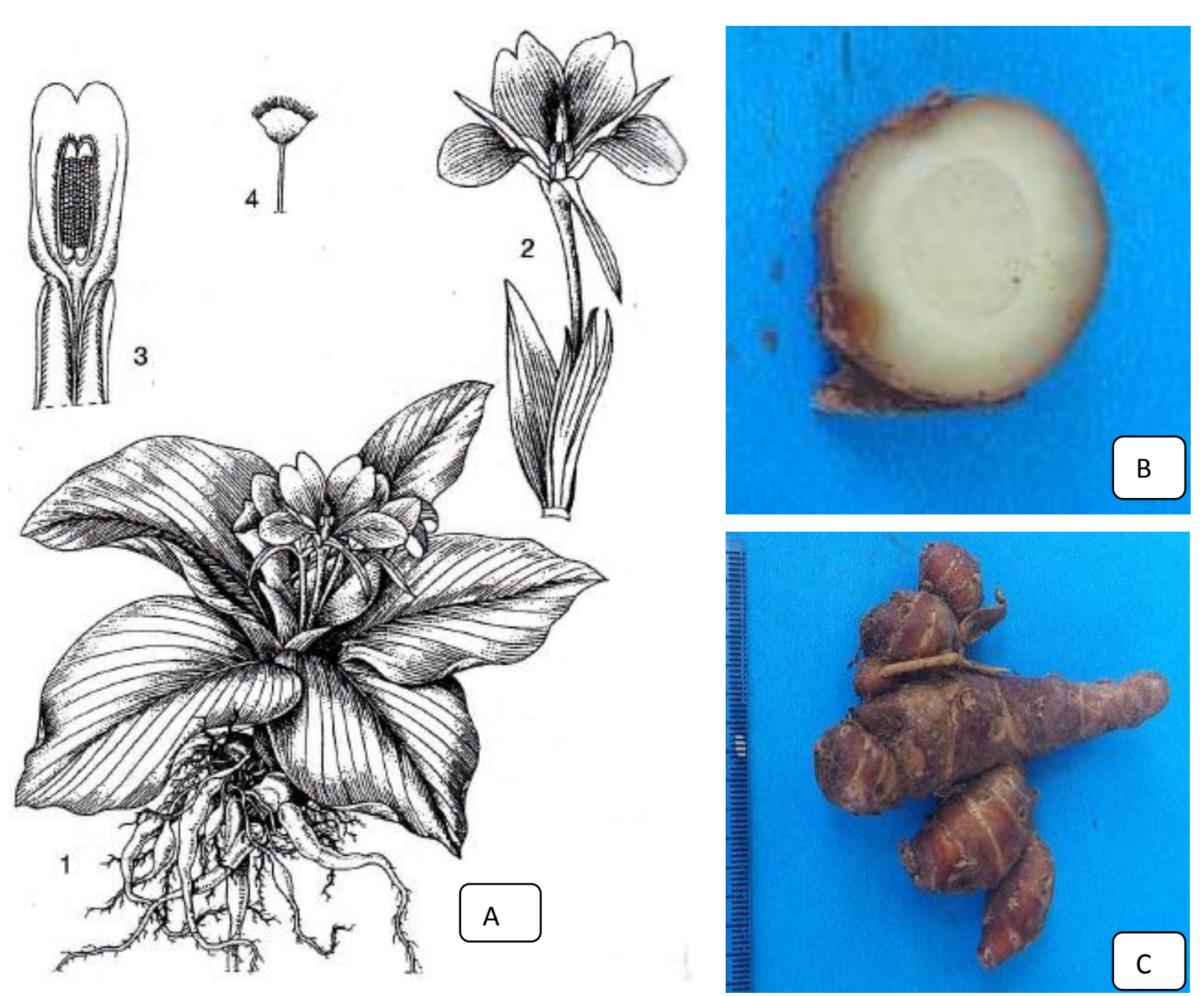

Gambar 1. Gambar ilustrasi Kaemferia galanga 1. Habitus, 2. Bunga, 3. Bagian apeks dari benang sari fertil, 4. Bagian ujung dari tangkai sari (Ibrahim 1998). B. Sayatan melintang rhizoma; C. Rhizoma K. galanga (Dokumen pribadi).

Strategi yang berbeda akan diperlukan untuk mengelola dan mempertahankan spesies poliploid ini secara efektif, misalnya tetraploid (Nopporncharoenku et al., 2017). Informasi sitogenetika bermanfaat dalam pengelolaan sumber daya genetik dan berkelanjutan penggunaan genus Kaemferia. Informasi sitogenetik bersifat mendasar dan dapat digunakan untuk mengevaluasi fertilitas dan produktivitas tanaman. Banyak sekali spesies rimpang Kaempferia ditanam di Thailand yang dikomersialkan memiliki kultivar campuran dengan berbagai tingkat ploidi dan karena perbedaanya didasarkan hanya pada sifat morfologin saja. Analisis sitogenetik, 
baik mitosis dan meiosis, dapat memberikan bukti mengenai evolusi spesies, hibridisasi dan poliploidi pada Kaemferia. Metode molekul sitogenetik dapat digunakan untuk untuk menjelaskan hubungan genomik dalam spesies poliploid dari genus Kaempferia (Nopporncharoenku et al., 2017).

Labooy et al., (2018) menyatakan bahwa urutan ribosom internal transkripsi spacer (ITS) dan karakteristik morfologi digunakan untuk mengidentifikasi spesies Kaempferia. Urutan ITS 4 dan 5 adalah diusulkan sebagai barcode DNA untuk identifikasi spesies Kaempferia. Ciri-ciri morfologis yang dapat digunakan untuk membedakan Kaemferia meliputi perawakan tanaman, warna rimpang dan variasi daun dapat digunakan sebagai identifikasi awal (Labooy et al., 2018).

\section{MANFAAT DAN BIOAKTIVITAS}

Rizoma KG telah lama digunakan sebagai obat untuk ekspektorat, karminatif (Chan et al., 2008), obat batuk, rematik, dan antikanker (Ibrahim 1998), kolera (Dash et al., 2014), vasorelaksasi, anti mikroba, antioksidan, anti alergi penyembuhan luka (Umar et al., 2011). Walaupun secara etnobotani banyak manfaat dari KF, namun pmengenai bioaktivitasnya membuktikan aktivitas KF sebagai anti kanker, anti oksidan, anti inflamasi, analgesik dan anti bakteri.

\section{Anti Kanker}

Kanker merupakan salah satu penyebab kematian manusia, yang disebabkan oleh pertumbuhan sel yang tidak terkendali. Berbagai faktor dilaporkan pemicu kanker yang disebut sebagai karsinogen beberapa diantaranya radiasi, virus, pewarna makanan. Karsinogen merupakan senyawa atau zat yang memicu perubahan materi genetik. Antineoplastik merupakan istilah yang digunakan untuk penggunaan obat atau senyawa untuk mengatasi penyakit kanker, oleh karena itu senyawa anti kanker memiliki aktivitas sebagai antionoplastik. Aktivitas antineoplastik dapat diukur melalui waktu hidup dan umlah sel tumor dan perubahan atau keruasakan morfologis inti sel.

Aktivitas KG sebagai anti kanker telah dilaporkan oleh Ibrahim (1998), Ali et al. (2018) dan Umar et al. (2018). KG memiliki aktivitas antineoplastik pada sel Ehrlich ascites carcinoma (EAC) diuji secara in vivo (Ali et al., 2018), dan ekstak etanol KF menunjukkan toksisitas melawan human carcinoma (HeLa) cells (CD50 10-30\% $\mu \mathrm{g} / \mathrm{ml})$ (Ibrahim 1998). Pemberian ekstrak KG secara signifikan ( $\mathrm{p}<0,05)$ menurunkan viabilitas sel EAC dan meningkatkan capaian dan lama hidupnya (Ali et al., 2018). Pemberian ekstrak metanol KG pada dosis 5 dan 
$10 \mathrm{mg} / \mathrm{kg}$ pada tikus yang diinduksi EAC menghasilkan peningkatan rentang hidup masingmasing sebesar 12,95\% dan 38,39\%, dibandingkan dengan analisis kontrol (p <0,05) (Ali et al., 2018).

Penghambatan maksimum pertumbuhan sel diamati pemberian ekstrak metanol KG pada dosis $10 \mathrm{mg} / \mathrm{kg}$ sebesar 70,58\% (Ali et al., 2018). Ekstrak metanol KG mengakibatkan memran sel blebbing, kondensasi kromatin, dan fragmentasi inti EAC (Ali et al., 2018). Mekanisme utama aktivitas ini melibatkan penghambatansintesis de novo dari sitokin pro-inflamasi,termasuk TNF-a dan IL-1. EPMC menunjukkan antiangiogenik yang dalamefek dalam uji cincin aorta tikus. Efek iniditemukan melibatkan penghambatan fungsi vitalsel endotel, seperti proliferasi, migrasi, dan tabungpembentukan, dan disebabkan oleh penghambatan sintesisfaktor pertumbuhan endotel vaskular dalam sel. Jadi, etil-pmethoxycinnamatedapat menjadi prekursor potensial untukpengembangan agen terapi dengan potensi untukmengobati penyakit yang melibatkan peradangan dan angiogenesis (Umar et al., 2011).

Senyawa asam 2-Propenoic, asam phthalic, asam palmitic, sandaracopima-radiene, asam oleic, asam octadecanoic, 2-[2-(4-nonylphenoxy) ethoxy] ethanol dan glycidyl stearate merupakan kompone utama dari ekstrak metanol KG yang dianalisi dengan GC-MS (Ali et al., 2018). Ethyl-p-methoxycinnamate yang telah berhasil diidentifikasi dari KG isolasi memiliki aktivitas antiangiogenic (Umar et al., 2014). Ethyl-p-methoxycinnamate sangat kuat menghambat jaringan granuloma tikus. Faktor penghambatan interleukin dan tumor necrosis oleh ethyl-p-methoxycinnamate adalah signifikan baik dalam model in vivo dan in vitro; namun, hanya penghambatan moderat nitrat oksida yang diamati pada makrofag. Ethylpmethoxycinnamate menghambat pertumbuhan pembuluh darah kecil aorta tikus dan sangat menghambat diferensiasi dan migrasi sel-sel endotel vaskular (Umar et al., 2014). Ethyl-pmethoxycinnamate menunjukkan potensi anti-inflamasi yang signifikan dengan menghambat sitokin dan angiogenesis proinflamasi, sehingga menghambat fungsi utama sel endotel. Dengan demikian, ethylp-methoxycinnamate bisa menjadi agen terapi yang menjanjikan untuk pengobatan penyakit terkait inflamasi dan angiogenesis (Umar et al., 2014).

Apoptosis merupakan sebuah mekanisme pengaturan intrinsic cell-suicidal melalui berbagai jalur pensinyalan sel yang ditndai penyusutan sel, kondensasi kromatin dan pembentukan tubuh apoptosis (Kabir et al., 2016). Kemampuan menginduksi apoptosis sangat diinginkan aspek obat antikanker karena proses ini secara selektif menghilangkankanker atau sel 
ganas tanpa merusak sel normal. Fluoresensianalisis mikroskopis sel yang diwarnai dengan Hoechst 33342, apewarna fluorescing biru yang menodai DNA kromatin, cepat dan nyamancara untuk mengamati fitur morfologi sel seperti nuclear fragmentation, chromatin condensation etc. Apoptosis dalam sel EAC oleh ekstrak metanol dikonfirmasi oleh studi tentang perubahan dalamkomponen nuklir dan bentuk sel yang dibandingkan dengan itusel EAC kontrol yang menunjukkan bahwa MEKGR dapat berperan secara signifikanperan dalam pencegahan kanker dengan menginduksi apoptosis. Sejumlah penelitianyang dilakukan sebelumnya juga melaporkan induksi apoptosisdalam sel EAC selama perawatan dengan ekstrak tanaman yang berbeda (Islam et al., 2014b). Polyphenolic senyawa dianggap paling penting dan berlimpahanti oksidan ditemukan di kerajaan tumbuhan dan telah diklaimuntuk memiliki kegiatan antikanker (Mates et al., 2008).

\section{Analgesik}

Efek antinociceptive ekatrak KG dibandingkan dengan aspirin (Umar et al., 2011). Anagesik merupakan senyawa yang berfungsi untuk mengurangi rasa sakit. Senyawa ini banyak digunakan untuk mengurangi penderitaan akibat luka, infeksi atau penyakit lainnya. Pada percobaan di laboratorium untuk menegetahui sifat analgesik KG dapat uji tail flick tikus (Umar et al., 2014). Lebih lanjut Umar et al., (2014) ethyl-p-methoxycinnamate KG memperpanjang waktu tail flick tikus lebih dari dua kali lipat dibandingkan dengan hewan kontrol. KF mengandung maksimum $(25,80 \mathrm{mg} / \mathrm{g})$ etil trans-p-metoksisinamat diperoleh pada ekstraksi kondisi suhu $120^{\circ} \mathrm{C}$, waktu ekstraksi 20 menit, tekanan ekstraksi $10 \mathrm{Mpa}$, daya ultrasonik kepadatan $250 \mathrm{~W} / \mathrm{L}$, dan frekuensi ultrasonik $20 \mathrm{kHz}$ (Ma et al., 2015).

\section{Anti Bakteri}

Bakteri merupakan salah satu kelompok mikroorganisme penyebab berbagai penyakit seperti diare, tuberkulosis, kolera, sipilis, dan antrak, oleh karena itu untuk mengatasi penyakit tersebut dimanfaatkan senyawa anti mikroba. KG telah lama digunakan untuk mengatasi berbagai gangguan kulit dan mengatasi kolera (Dash et al., 2014), batuk dan ganguan tengorokan (Ibrahim 1998), Lakshmanan et al., 2011) merupakan penyakit yang disebabkan oleh infeksi mikroba. Berbagai metode dikembangkan untuk menguji aktivitas anti mikroba antara lain metode difusi dan zona hambat terhadap mikroorganisme (Dash et al., 2014).

Tuberculosis merupakan salah satu jenis infeksi paru-paru yang disebkan oleh bakteri Mycobacterium tuberculosis (Lakshmanan et al., 2011), dan hingga saat ini masih merupakan 
salah satu masalah kesehatan termasuk di Indonesaia. Berbagai jenis obat telah dikembangkan untuk mengatasi tuberkulosis, namun seiring dengan waktu muncul resitensi terhadap obat, oleh karena itu pencarian senyawa baru yang dapat menghambat pertumbuhan $\mathrm{M}$. tuberculosis tetap dilakukan termasuk KF. Lakshmanan et al., (2011) menyatakan KF memang memiliki prinsip aktif yang dapat menghambat $M$. Tuberculosis dan dengan demikian membenarkan dimasukkannya tanaman dalam ramuan dalam pengobatan TB. Hal yang hampir mirip juga dilaporkan oleh Dash et al., (2014) bahwa ekstrak KG pada konsentrasi $400 \mu \mathrm{g} /$ disc memiliki aktivitas sebagai antibakteri Gram positif dan bakteri Gram negatif dengan aktivitas sedang bila dibandingkan dengan obat standar ciprofloxacin (5 $\mu \mathrm{g} / \mathrm{disc})$ (Dash et al., 2014). Kaempferia galanga, menghasilkan molekul anti-TB yaitu etil p-metoksisinamat (EPMC). Uji resazurin mikrotiter (REMA), EPMC terbukti menghambat M. tuberculosis H37Ra, H37Rv, isolat klinis yang peka terhadap obat dan multidrug resistant dengan konsentrasi hambat minimum sebesar 0,242-0,485 mM (Lakshmanan et al., 2011). Volatil oil KG dengan menggunakan metode disc difusi memiliki zona hambat terhadap mikroba dengan luas zona sebesar 8.0- $31.0 \mathrm{~mm}$ (IC50 $>100 \mu \mathrm{g} / \mathrm{ml})$ (Tewtrakul et al., 2005).

\section{Anti Inflamasi}

Radang atau inflamasi merupakan respon protektif setempat yang ditimbulkan oleh cedera atau kerusakan pada jaringan yang berfungsi untuk menghancurkan, mengurangi, atau melokalisasi (sekuster) baik agen pencedera maupun jaringan yang cedera itu (Hasanah et al., 2011). Reaksi inflammatori melibatkan reaksi aktivasi sejumlah aktivasi sejumlah jalur intraseluler berbeda yang mengarah keinduksi gen pro-inflamasi spesifik, termasuk yang mengkode interleukin-1 (IL-1) dan nekrosis tumorfaktor-a (TNF-a) (Hanada et al., 2002). Misalnya, perlekatan bakteri antigen ke reseptor seperti tol di permukaan makrofagdan sel dendritik menghasilkan aktivasi jalur protein kinase teraktivasi mitogen (MAPK / NF-kBjalur), yang mengarah pada induksi proinflamasi pengkodean gen IL-1, TNF-a, cyclooxygenase-2 (COX-2), and inflammatory nitric oxide (iNO) (Hanada et al., 2002). Etil-pmethoxycinnamate yang diisolasi dari yang dimiliki KG memeiliki aktivitas efek antiinflamasi yang signifikan (Umar et al., 2011).

Hasil pengujian aktivitas antiinflamasi menunjukkan bahwa ekstrak rimpang KF dari

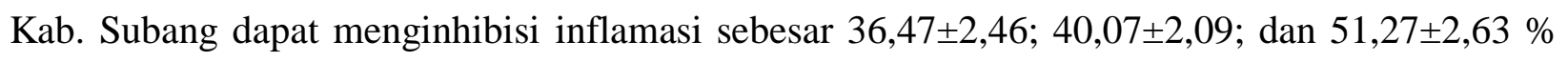

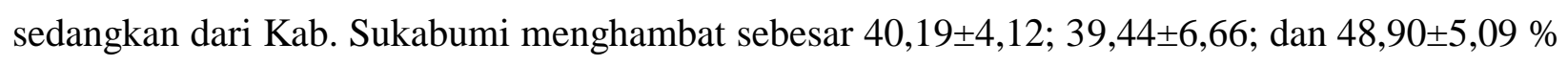


berturut-turut pada dosis 18, 36, dan $45 \mathrm{mg} / \mathrm{kg}$ bobot badan tikus. Kadar minyak atsiri ekstrak rimpang kencur dari Kab. Subang lebih kecil yaitu sebesar 5,825\% dibandingkan kadar minyak atsiri ekstrak kencur dari Kab. Sukabumi (14,41\%), namun rimpang kencur dari Kabupaten Subang maupun dari Sukabumi mengandung minyak atsiri yang sama yaitu 2,4,6-trimetil oktan, etilsinamat, limonen dioksida, asam etil ester 3-(4-metoksifenil)-2-propenoat, dan etil pmetoksisinamat (Hasanah et al., 2011).

\section{Antioksidan}

Tubuh secara menghasilkan reactive oxygen species (ROS), namun produksi ROS yang berlebihan mengakibatkan kerusakan jaringan dan hilangnya fungsi jaringan dan organ. ROS sangat berbahaya dan mengakibatkan kerusakan protein, DNA dan lipid oleh karena itu memulai berbagai penyakit kronis seperti kanker, atherosclerosis, diabetes, cardiovascular disease,

penuaan dan penyakit inflamasi (Islam et al., 2013). Senyawa yang mampu mengurangi atau menghambat radikal bebas disebut sebagai senyawa antioaksidan. Pemanfaatan bahan alam sebagai antioksidan banyak diminati dan penelitiannya semakin banyak dilakukan. Bioaktivitas KG sebagai antioksidan telah dilaporkan oleh Ali et al. (2018) dan Chan et al. (2008).

Metabolit sekunder tanaman memiliki peran penting dalam menyeimbangkan status redoks intraseluler dan fungsi antioksidan (Ali et al., 2018). Bioaktivitas tumbuhan sebagai antioksidan berhubungan dengan senyawa flavonoid. Ali et al., (2018) menyatakan bahwa flavonoids KG menunjukkan korelasi yang sangat kuat $\left(\mathrm{R}^{2}=0.985\right.$, $\left.\mathrm{p}<0.05\right)$ dengan aktivitas pemulungan nitrat oksida (Ali et al., 2018). Aktivitas KG sebagai antioksidan dipengaruhi oleh jenis organ yang digunakan dan kandungan senyawa phenoloknya. Daun KF memiliki aktivitas sebagai anti radikal bebas dan metal ion-chelating lebih tinggi dibandingkan dengan rhizoma (Chan et al., 2008). TPC (total phenolic content) dan TFC (total flavonoid content) KG berhubungan sangat kuat dengan aktivitas sebagai antioksidan (Ali et al., 2018).

\section{Anti Hipertensi}

KG telah lama digunakan sebagai anti hipertensi oleh berbagai kelompok masyarakat di Malaysia dan Indoneia (Ibrahim 1998). Munin dan Hanani (2011) menyatakan bahwa hipertensi adalah keadaan dimana tekanan darah lebih dari $160 \mathrm{mmHg}$ pada sistol dan $95 \mathrm{mmHg}$ pada diastol. Tumbuhan yang dapat digunakan sebagai anti hipertensi merupakan tumbuhan yang memeberi efek dilatasi pada pembuluh darah dan penghambatan angiotensin converting enzyme 
da dapat juga dikombinasikan dengan tumbuhan yang memberi efek penenang (Munin dan Hanani 2011).

Ekstrak diklorometana rhizoma KG memiliki aktivitas sebagai anti hipertensi (Othman et al., 2006). Senyawa anti hipertensi merupakan senyawa essensial oil. Rhizoma KG mengandung sekitar 0,29\% essensial oil. Asam etil p-metoksisinamat yang diisolasi dari KG tetapi tidak menunjukkan efek relaksasi pada aorta tikus torak prekontrak (Othman et al., 2006). Pemberian intravena ekstrak KG menginduksi tekanan arteri rerata basal $(1306 \mathrm{mmHg}$ ) pada tikus anestesi dan efek maksimal terlihat setelah 5-10 menit injeksi. Kromatogram gas menunjukkan senyawa yang sama dalam fraksi aktif yang diperoleh dari fraksinasi yang dipandu bioassay dari ekstrak diklorometana adalah etil sinamat. Senyawa aktif vasorelaksan, etil sinamat, diisolasi sebagai minyak tidak berwarna (Othman et al., 2006).

\section{Penyembuhan Luka}

Luka merupakan terbukanya jaringan kulit karena gangguan fisik maupun kimia. Luka merupakan salah satu lokasi masuknya mikroba ke dalam tubuh, oleh karena itu perlu usaha penutupan jaringan yang terbuka. Ekstrak alkohol KF memiliki aktivitas untuk menyembuhkan luka pada tikus percobaan. Ekstrak KG mengurangi waktu yang dibutuhkan untuk epitelisasi (Tara et al., 2006).

\section{SIMPULAN}

Ethyl-trans-p-methoxy cinnamate dan trans-ethyl cinnamate merupakan senyawa utama yang sangat penting pada $K$. galanga dan merupakan komponen yang memiliki sifat pharmakologi. Secara etnobotani $K$. galanga digunakan sebagai obat ekspektorat, karminatif, obat batuk, rematik, dan anti kanker, kolera, vasorelaksasi, anti mikroba, antioksidan, anti alergi penyembuhan luka. Bioaktivitasnya membuktikan aktivitas $K$. galanga sebagai anti kanker, anti oksidan, anti inflamasi, analgesik dan anti bakteri.

\section{DAFTAR PUSTAKA}

Ali, R., Yesmin, R., Satter, M.A., Habib, R., \& Yeasmin, T. (2018). Antioxidant and antineoplastic activities of methanolic extract of Kaempferia galanga Linn. Rhizome against Ehrlich ascites carcinoma cells. Journal of King Saud University Science 30, 386392. 
Chan, E.W.C., Lim, Y.Y., Wong, L.F., Lianto, F.S., Wong, S.K., \& Lim, K.K. (2008). Antioxidant and tyrosinase inhibition properties of leaves and rhizomes of ginger species. Food Chemistry 109, 477-483.

Dash. P.R., Nasrin. M., \& Shawkat. M. (2014). In vivo cytotoxic and In vitro antibacterial activities of Kaempferia galanga. Journal of Pharmacognosy and Phytochemistry 3(1): 172-177.

de Guzman, C.C., \& Siemeonsma. (1999). Plant resources of South East Asia Spices (13). Backhuys Publishers, Leiden.

Fabricant, D.S., \& Farnsworth, N.R. (2001). The value of plant used medicine for drug discovery. Enviromental Health Perspective 109(1): 69-75.

Hanada, T., \& Yoshimura, A. (2002). Regulation of cytokine signaling and inflammation. Cytokine Growth Factor Rev. 13(4-5), 413-21.

Hasanah, A.N., Nazaruddin. F., Febrina. E., \& Zuhrotun. A. (2011). Analisis Kandungan Minyak Atsiri dan Uji Aktivitas Antiinflamasi Ekstrak Rimpang Kencur (Kaempferia galanga L.). Jurnal Matematika \& Sains 16(3): 147-152

Harborne, J.B. (1987). Metode fitokimia: Penuntun cara modern menganalisis tumbuhan, Ed. II. Diterjemahkan oleh Kosasih Padmawinata dan Iwang Soedira. Bandung: ITB Press.

Ibrahim, H. (1999). Kaemferia galanga L. in: Plant Resources of South East Asia No 12(1) Medicinal and Poisinous Plants 1, de Padua LS, N. Bunyapraphhatsara and RHMJ Lemmens (editor). Backhuys Pblisher Leiden. P. 334.

Indrayan, A.K., Kurian, A., Tyagi, P.K., Shatru, A., \& Rathi, A.K. (2007). Comparative chemical study of two varieties of attractive medicinal plant Kaempferia galanga L. Nat. Prod. Rad. 6: 327-333.

Islam, S., Nasrin. S., Khan, M.A., Hossain, A.S.M., Islam, F., Khandokhar, P., Mollah, M.N.H., Rashid, M., Sadik, G., Rahman, M.A.A,, \& Alam, H.M.K.A. (2013). Evaluation ofantioxidant and anticancer properties of the seed extracts of Syzygium fruticosum Roxb. growing in Rajshahi, Bangladesh. BMC Complement. Altern. Med. 13, 142.

Islam, F., Ghosh, S., \& Khanam, J.A. (2014)a. Antiproliferative and hepatoprotective activity of metabolites from Corynebacterium xerosis against Ehrlich ascites carcinoma cells. Asian Pac. J. Trop. Biomed. (4) 284-292. 
Islam, F., Khatun, H., Khatun, M., Ali, S.M., \& Khanam, J.A. (2014)b. Growth inhibition and apoptosis of Ehrlich ascites carcinoma cells by the methanol extract of Eucalyptus camaldulensis. Pharm. Biol. (52) 281-290.

Kabir, S.R., Rahman, M.M., Amin, R., Karim, M.R., Mahmud, Z.H., \& Hossain, M.T. (2016). Solanum tuberosum lectin inhibits Ehrlich ascites carcinoma cells growth by inducing apoptosis and G2/M cell cycle arrest. Tumor Biol. (37), 8437-8444.

Larsen, K. (1980). Annotated key to the genera of Zingiberaceae of Thailand. Nat. Hist. Bull. Siam Soc. (28) 151-169

Labrooy, C.D., Abdullah, T.L., \& Stanslas, J. (2018). Identification of ethnomedicinally important Kaempferia L. (Zingiberaceae) species based on morphological traits and suitable DNA region. Current Plant Biology 14: 50-55.

Lakshmanan, D., Werngren, J., Jose, L., Suja, K.P., Nair, M.S., Varma, R.L., Mundayoor, S., Hoffner, S., \& Kumar, R.A. (2011). Ethyl p-methoxycinnamate isolated from a traditional anti-tuberculosis medicinal herb inhibits drug resistant strains of Mycobacterium tuberculosis in vitro. Fitoterapia (82) 757-761.

Liu, X.C., Liang, Y., Shi, W.P., Liu, Q.Z., Zhou, L., \& Liu, A.Z.L. (2014). Repellent and insecticidal effects of the essential oil of Kaempferia galanga rhizomes to Liposcelis bostrychophila (Psocoptera: Liposcelidae). J. Econ. Entomol. 107(4), 1706-1712.

Mates, J.M., Segura, J.A., Alonso, F.J., \& Marquez, J. (2008). Intracellular redox status and oxidative stress: implications for cell proliferation, apoptosis, and carcinogenesis. Arch. Toxicol. (82) 273-299.

Ma, Q., Fan, X.D., Liu, X.C., Qiu, T.A., \& Jiang, J.G. (2015). Ultrasound-enhanced subcritical water extraction of essential oils from Kaempferia galangal L. and their comparative antioxidant activities. Separation and Purification Technology (150) 73-79.

Munin, A., \& Hanani, E. (2011). Fitoterapi Dasar. Dian Rakyat: Jakarta.

Nayar, M.P. (1985). Meaning of Indian Flowering Plant Names. Bishen Singh Mahendra Pal Singh, Dehradun: 409.

Nopporncharoenkul, N., Chanmai, J., Jenjittikul, T., Jhonsson, K.A., \& P, Soontornchainaksaeng. (2017). Chromosome number variation and polyploidy in 19 Kaempferia (Zingiberaceae) taxa from Thailand and one species from Laos. Journal of Systematics and Evolution 55(5), 466-476. 
Othman, R., Ibrahim, H., Mohd, M.A., Mustafa, M.R., \& Awang, K. (2006). Bioassay-guided isolation of a vasorelaxant active compound from Kaempferia galanga L. Phytomedicine 13: 61-66.

Raina, A.P., Abraham, Z., \& Sivaraj, N. (2015). Diversity analysis of Kaempferia galanga L. germplasm from South India using DIVA-GIS approach. Industrial Crops and Products 69: 433-439.

Rajendra, C.E., Magadum, G.S., Nadaf, M.A., Yashoda, S.V., \& Manjula, M. (2011). Phytochemical screening of the rhizome of Kaempferia galanga. International Journal of Pharmacognosy and Phytochemical Research, 3(3), 61-63.

Silalahi, M. (2019). Keanekaragaman tumbuhan bermanfaat di pekarangan oleh Etnis Sunda di Desa Sindang Jaya Kabupaten Cianjur Jawa Barat. Jurnal Pendidikan Matematika dan IPA, 10(1), 88-104.

Silalahi, M., Supriatna, J., Walujo, E.B, \& Nisyawati. (2015). Local knowledge of medicinal plants in sub-ethnic Batak Simalungun of North Sumatra, Indonesia. Biodiversitas. 16(1), 44-54.

Silalahi, M., Nisyawati., Walujo, E.B., Supriatna, J., \& W, Mangunwardoyo. (2015). The local knowledge of medicinal plants trader and diversity of medicinal plants in the Kabanjahe traditional market, North Sumatra, Indonesia. Journal Ethnopharmacology 175, 432-443.

Silalahi, M \& Nisyawati. (2018). An ethnobotanical study of traditional steam-bathing by the Batak people of North Sumatra, Indonesia. Pacific Conservation Biology https://doi.org/10.1071/PC18038: 1-17.

Taiz, L., \& Zeiger, E. (2006). Plant Physiology. Sinauer Associates, Inc, Sunderland: xxvi+ 764 hlm.

Tara, S.V., Chandrakala, S., Sachidananda, A., Kurady, B.L., Smita, S., \& Ganesha, S. (2006). Wound healing activity of alcoholic extract of Kaempferia galanga in wistar rats. Indian J Physiol 50(4), 384-390. 